\title{
Global Structural Exploitation: Towards an Intersectional Definition
}

\begin{abstract}
If Third World women form 'the bedrock of a certain kind of global exploitation of labour,' as Chandra Mohanty argues, how can our theoretical definitions of exploitation account for this? This paper argues that liberal theories of exploitation are insufficiently structural and that Marxian accounts are structural but are insufficiently intersectional. What we need is a structural and intersectional definition of exploitation in order to correctly identify global structural exploitation. Drawing on feminist, critical race/post-colonial and post-Fordist critiques of the Marxist definition and the intersectional accounts of Maria Mies and Iris Marion Young, this paper offers the following definition of structural exploitation: structural exploitation refers to the forced transfer of the productive powers of groups positioned as socially inferior to the advantage of groups positioned as socially superior. Global structural exploitation is a form of global injustice because it is a form of oppression.

Keywords: Exploitation; feminism; global justice; Iris Marion Young; Maria Mies; Marxism
\end{abstract}

\section{Introduction}

In both rich and poor countries, women's participation in the labour market has significantly increased since the 1970s. However, this increase has not been accompanied by a redistribution of domestic labour and childcare; women are still disadvantaged in terms of lower wages, lack of training and occupational segregation; and they are disproportionately involved in temporary, parttime, casual and home-based labour. ${ }^{1}$ Third World women, in particular, have entered the labour market as a cheap, flexible and, for the most part, ununionised labour force. For instance, in 2006, there were Export Processing Zones (EPZs) in 130 countries, employing 66 million people, 70\%-80\% of whom were women. ${ }^{2}$ More women are now migrating for work, constituting half of the world's legal and illegal migrant workers, and they are over-represented in certain occupations - sex work, care work and domestic work. ${ }^{3}$ As Chandra Talpade Mohanty argues, despite the fact that the labour of Third World women workers forms 'the bedrock of a certain kind of global exploitation of labour,'

1 Valentine M. Moghadam, ‘Gender and the Global Economy’ in Myra Marx Ferree, Judith Lorber and Beth B. Hess (eds.), Revisioning Gender (Oxford: Alta Mira Press, 200o), 134-147, p. 135.

2 Hye-Ryoung Kang, 'Transnational Women's Collectivities and Global Justice' in Alison M. Jaggar (ed.), Gender and Global Justice (Cambridge: Polity Press, 2014), 40-62, p. 43.

3 Barbara Ehrenreich and Arlie Russell Hochschild, 'Introduction' in Global Woman: Nannies, Maids, and Sex Workers in the New Economy (London: Granta Books, 2003), 1-15, p. 5. 


\section{GLOBAL STRUCTURAL EXPLOITATION: TOWARDS AN INTERSECTIONAL DEFINITION}

that 'this way of reading the operation of capital ... remains somewhat invisible and undertheorised.' 4

Until now, theories of Global Justice have focused on the unjust global distribution of resources. Within this liberal paradigm, which is primarily concerned with what individuals have, other forms of injustice related to how individuals are treated have been neglected. ${ }^{5}$ Furthermore, this framework is silent on the exploitation of Third World women workers. In the second political understanding of injustice, myriad forms of global injustice reveal themselves, including global structural exploitation. ${ }^{6}$ In this paper, I work towards a definition of global structural exploitation as a way of identifying this injustice, to render it visible and to begin to theorise it.

Two immediate objections present themselves to such a project. The first is that although global structural exploitation is a problem, it is not the most urgent problem. Marginalisation from the global economy, rather than the mistreatment of employed individuals, is more important because it results in extreme poverty. The upshot is that we should focus our attention, both theoretical and practical, there. My response is that of course marginalisation is unjust, but this does not mean that exploitation is not also an injustice and thus deserving of our attention. There is a wealth of literature, both theoretical and empirical, on poverty, but a lot less on exploitation. Moreover, it is not only wage-workers (traditionally conceived of as the only agents engaged in 'productive' labour) who are exploited. Non-wage workers, primarily women, are also exploited, and that exploitation is invisible. Those who are marginalised from the economy in an official sense often contribute to the economy in an unofficial sense (reproducing the labour force, doing unpaid domestic labour,

4 Chandra Talpade Mohanty, Feminism without Borders: Decolonizing Theory, Practicing Solidarity (USA: Duke University Press, 2003), p. 145. Mohanty uses the term 'Third World women' to refer to 'both women from the geographical Third World and immigrant and indigenous women of color in the United States and Western Europe' (p. 144). Mohanty argues that the term is not essentialising and does not aim to capture particular experiences; rather, it refers to the 'common interests' of workers similiarly positioned in racialised and gendered global labour markets. I follow Mohanty in using the term in this sense. Of course, the term 'Third World' is also problematic and controversial, but Mohanty and other post-colonial thinkers have reclaimed it because it is a politicised term that refers to the project of such states resisting the heirarchy between the 'First' and 'Third' worlds, and it better captures this politicised, heirarchical relationship than alternative terminology such as 'developing' vs. 'developed' countries (see Rahul Rao, Third World Protest: Between Home and the World (Oxford: Oxford University Press, 2010), p. 24-30).

5 These two competing views of justice are taken from Rainer Forst, 'Radical Justice: On Iris Young's Critique of the "Distributive Paradigm”, Constellations 14/2 (2007), 260-265.

6 For instance, Iris Marion Young identifies two forms of injustice - domination and oppression. She identifies 'five faces of oppression' in the contemporary USA - marginalisation, powerlessness, exploitation, cultural imperialism and violence - and suggests that there may be different relations of oppression in the international context. Iris Marion Young, Justice and the Politics of Difference (Princeton: Princeton University Press, 1990), Chs. 1, 2 and Epilogue. 
or off-the-books wage labour). ${ }^{7}$ Exploitation can intersect with, and is often an outcome of, marginalisation, which is something we forget if we solely focus on marginalisation.

The second objection is that it is foolhardy to tie a theory of global injustice to a theory of exploitation because no consensus definition of exploitation exists. ${ }^{8}$ Although there is truth to this claim, my response is that this is not a sufficient reason to reject a theory of global structural exploitation; instead, it is a reason to contribute to the conceptual labour of building one. This paper aims to contribute to this task.

The aim, more specifically, is to work towards a definition of global structural exploitation that is fundamentally intersectional. ${ }^{9}$ If it is true that Third World women form the bedrock of the globally exploited, we need a definition that incorporates gender, 'race' and class from the outset, something that is lacking in contemporary exploitation literature. My main claim is this: liberal theories of exploitation are insufficiently structural; Marxian theories are structural but insufficiently intersectional; what we need is a structural and intersectional definition of exploitation in order to correctly identify global structural exploitation.

In Part I, I outline contemporary liberal theories of exploitation. I argue that while these theories help in providing an account of transactional exploitation (exploitation of one agent by another), they are inadequate for describing structural exploitation. In Part II, I outline the technical Marxist definition of exploitation and its critics. Feminist, anti-racist and post-Fordist Marxian theorists have critiqued the classical Marxist conception as being sex-blind, race-blind and overly reliant on an out-dated conception of productive labour. I demonstrate the inadequacies of both the liberal and Marxist approaches by giving the example of the global migration of women for domestic and care work. In Part III, I examine Maria Mies' and Iris Marion Young's attempts to define structural exploitation intersectionally and propose a synthesis of their accounts. I propose the following intersectional definition of structural

7 For instance, see Maria Mies' discussion of the work of rural Indian women in the state of Andhra Pradesh. Maria Mies, Patriarchy and Accumulation on a World Scale: Women in the International Division of Labour, 3rd Edition (London: Zed Books, 2014), p. 128-131.

8 Margaret Moore, 'Global Justice and the Connection Theory of Responsibility' in Genevieve Fuji Johnson and Lorlea Michaelis (eds.), Political Responsibility Refocused: Thinking Justice after Iris Marion Young (London: University of Toronto Press, 2013), 21-41, p. 25.

9 The term intersectionality derives from Black feminist thought and is often traced back to the Combahee River Collective Statement of 1977. It was popularised in academia by Kimberlé Crenshaw's 1989 article and her subsequent work. Kimberlé Crenshaw, 'Demarginalizing the Intersection of Sex and Race: A Black Feminist Critique of Antidiscrimination Doctrine, Feminist Theory, and Antiracist Politics', University of Chicago Legal Forum 139 (1989), 139-168. For an overview of the evolution of the concept in feminist theory see Anna Carastathis, 'The Concept of Intersectionality in Feminist Theory', Philosophy Compass 9/5 (2014), 304-314. 
exploitation: structural exploitation refers to the forced transfer of the productive powers of groups positioned as socially inferior to the advantage of groups positioned as socially superior. This definition incorporates feminist, anti-racist and post-Fordist critiques by relying on 'productive powers' instead of 'productive labour.' The definition is neutral as to which groups are socially superior/inferior and will be filled in differently in different socio-historical contexts. This definition explains why structural exploitation occurs across axes other than, but still including, class. This paper focuses on a descriptive account of structural exploitation, with an awareness of the fact that the concept is normatively laden, and concludes with some normative implications. In particular, it is suggested, following Young, that structural exploitation is a form of oppression because it necessarily inhibits the selfdevelopment of exploited groups.

\section{Liberal Theories of Exploitation}

Debates about exploitation abounded in the analytical Marxism literature of the 1970 s and 1980s. However, with the decline of analytical Marxism after the fall of the Berlin Wall and the rising hegemony of liberal political philosophy in the 1990s and 2000s, the Marxian approaches fell out of fashion, and liberal accounts have come to dominate the contemporary literature. In this section, I argue that contemporary liberal accounts of exploitation cannot help us define global structural exploitation.

Alan Wertheimer's 1996 book Exploitation has been credited with reviving the dormant liberal tradition of analysing exploitation between individuals. ${ }^{10}$ He cites the liberal focus on ideal theory and macro social justice as a reason for previously ignoring exploitation because, according to Wertheimer, exploitation is 'a micro-level wrong to discrete individuals in distinct relationships and transactions.' 11

Wertheimer argues that all theories of exploitation have a common core; the 'lowest common denominator' understanding of exploitation is that 'A exploits $\mathrm{B}$ when A takes unfair advantage of B.' ${ }^{12}$ The crux of the issue for liberal accounts of exploitation is that we need to explain what is unfair about the transaction. It cannot simply be a case of harm, for example, A violates B's rights, because that is a straightforward wrong upon which theorists of all stripes can agree. Harm is not a necessary condition of exploitation. ${ }^{13}$

10 Ruth Sample, Exploitation: What It Is and Why It's Wrong (Oxford: Rowman and Littlefield Publishers, 2003), p. 16; Matt Zwolinski, 'Structural Exploitation', Social Philosophy and Policy 29/1 (2012), 154-179, p. 158.

11 Alan Wertheimer, Exploitation (Princeton: Princeton University Press, 1996), p. 8.

12 Ibid.p. 10.

13 Robert E. Goodin, 'Exploiting a Situation and Exploiting a Person' in Andrew Reeve (ed.), Modern Theories of Exploitation (London: Sage Publications, 1987), 166-192, p. 179; Sample (2003) 
Force or coercion is also ruled out as the source of the unfairness because, as Robert Goodin argues, exploitation involves some degree of co-operation from the exploitee. ${ }^{14}$ Exploitation can be mutually beneficial. Wertheimer gives the example of a snowstorm. A hardware store owner doubles the price of shovels from $\$ 15$ to $\$ 30$. B buys the shovel because she needs it - both parties gain but B feels exploited because she pays more than she thinks is reasonable. ${ }^{15}$ Another contender is the lack of reciprocity involved in exploitative transactions. However, giving a gift is a non-reciprocal transaction, but that does not make it exploitative. ${ }^{16}$ Unequal benefits are also insufficient because almost all transactions would be exploitative on these grounds. ${ }^{17}$

There seems to be some consensus supporting the idea that using people is a necessary condition for exploitation. ${ }^{18}$ Yet, the issue is the way in which the person is being used. ${ }^{19}$ As Goodin argues, standing in the shadow of a large spectator in a crowd to avoid the sun is using that person, but it is not unfairly using that person. ${ }^{20}$ So what counts as unfair using? Goodin argues that unfair using occurs when the used party is already vulnerable. Exploitation is parasitic upon a duty to protect the vulnerable: 'It is the flagrant violation of this duty - playing for advantage when morally you are bound not to do so - which we call exploitation.' ${ }^{21}$ Wertheimer disagrees that the exploitee has to be vulnerable. For instance, in the snow shovel example, even if the customer is much richer than the hardware store owner, charging twice the going rate for the shovel can still be considered exploitative. ${ }^{22}$ Wertheimer argues that to assess whether or not a transaction is exploitative, 'we evaluate the parties' gains by what they would have received under relatively perfect market conditions. ${ }^{23}$ The hypothetical market price is the normative baseline for judging whether or not specific transactions are exploitative. ${ }^{24}$

Ruth Sample criticises both solutions. Against Wertheimer, she argues that his conception leads to counterintuitive results. For instance, why should a

14 Goodin (1987), p. 175 .

15 Wertheimer (1996), p. 22. Libertarian theorist Matt Zwolinski draws on this idea to claim that sweatshop labour may be exploitative, but it is not wrongfully exploitative because it is mutually beneficial. Zwolinski argues that if multi-national corporations did not establish sweatshops in developing countries, then the benefits that result from sweatshop labour, in the form of jobs, higher wages and economic growth, would not occur; it would be worse to neglect these workers. Zwolinski (2012), p. 169-170.

16 Goodin (1987), p. 175 .

17 Sample (2003), p. 13.

18 Goodin (1987), p. 180; Sample (2003), p. 12; Wertheimer (1996), p. 24.

19 Goodin (1987), p. 180.

20 Ibid. p. 179.

21 Ibid. p. 167.

22 Alan Wertheimer and Matt Zwolinski, 'Exploitation' in Edward N. Zalta (ed.), The Stanford Encyclopedia of Philosophy (2013), <https://plato.stanford.edu/archives/fall2016/entries/exploitation/>.

23 Ibid.

24 Ibid. 
market trader in a developing country not charge an affluent foreigner twice the market price for some fruit when it is pennies to the foreigner and makes a significant difference to the trader? ${ }^{25}$ Moreover, Wertheimer's solution is too conservative. Conceiving of the normative baseline as a fair market price relies too heavily on adherence to convention, which divests exploitation of its critical bite. ${ }^{26}$ Against both Goodin and Wertheimer, she argues that they cannot adequately account for exploitation in intimate relationships. Sample understands exploitation in a neo-Kantian sense. Instead of focusing on the unfairness of transactions, she invokes the utilisation of people as a means to an end in a degrading way. In exploitative transactions, 'The badness stems from the degradation of one or more of the agents in a transaction for advantage. Degradation is, on my view, treating someone or something as having less value than that person or thing actually has. ${ }^{27}$

Defining exploitation, then, is a tricky business. However, I do not think that constructing a structural account of exploitation requires solving these conceptual problems. My complaint with these 'transactional' accounts of exploitation is that they focus on transactions between individuals. What has been lost in these accounts of exploitation is the fundamental Marxian insight that exploitation can occur between groups. Moreover, exploitation is not necessarily a conscious agreement between transacting parties; instead, it is a structural phenomenon built into the economic system. As I will shortly demonstrate, one does not have to adopt a classical Marxist understanding of exploitation to accept that exploitation can occur between groups and that it can be structural.

A structural account will not address the kinds of concerns that liberal theorists have expressed about exploitation. It will not address the 'micro-level' transactions that Wertheimer has identified or the problem of exploitation in intimate relationships that motivates Sample's account. However, I would argue that rather than showing that there is no place for a conception of structural exploitation, this indicates that there is not one core conception of exploitation. Exploitation is, arguably, better categorised as a 'family resemblance' concept. I think that it is more productive to understand exploitation as a family resemblance concept and admit that there may be different kinds of moral wrong at play when exploitation occurs in intimate relationships, market transactions or within economic, social or political systems. The need to find the 'core' of exploitation, which can cover all these importantly different cases, seems to me a mistaken approach.

25 Sample (2003), p. 23.

26 Ibid, p. 24.

27 Ibid, p. 4. 
Although much more needs to be said about conceiving of exploitation as a family resemblance concept, it is beyond the scope of this paper as I primarily focus on structural exploitation. ${ }^{28}$ Of course, transactional, or micro-level exploitation, is of philosophical interest. I contend, however, that we cannot understand global phenomena like sweatshop labour or women's mass migration for domestic and care work without first obtaining some understanding of structural exploitation.

For example, in the contemporary world, women are migrating in their millions from poor to rich countries to work as care-givers and maids. ${ }^{29}$ According to the International Labour Organisation (ILO), in 2010 there were 52.6 million domestic workers globally 'employed in or by a private household or households'30; an increase of 19 million from the mid-1990s, constituting $7.5 \%$ of women's wage employment worldwide. ${ }^{31}$ On a transactional account, we could consider the ways in which these women are transactionally exploited by private employers - exploited as individuals by other individuals who take unfair advantage or use the employees in a degrading way. But this is insufficient, because the global migration of women for domestic and care work is a structural phenomenon. To debate about whether each individual is exploited on a case-by-case basis is to ignore the bigger picture. Why is it that women are migrating en masse from poor to rich countries to engage in this kind of labour? In what way is this exploitative? I will now examine the Marxist conception of exploitation and consider whether it can better capture this phenomenon.

\section{Marxian Theories of Exploitation}

For Marx, exploitation is primarily a technical concept. Richard Arneson describes the technical conception as 'the appropriation by a class of nonworkers of the surplus product of a class of workers.' ${ }^{2}$ As wage labourers, workers

28 My suspicion is that exploitation is related to power (power also conceived of as a family resemblance concept). Goodin argues, for instance, that what lies at the heart of the idea of 'taking advantage' is 'an abuse of power' (p. 184). In all the examples, we can see the involvement of 'power over' another person. In Wertheimer's snow shovel example, the hardware store owner has power over the customer insofar as she has something the customer urgently needs. In Goodin's definition of exploitation, if the potentially exploited agent is vulnerable in relation to a potential exploiter, then the potential exploiter necessarily has power over them. However, this is too complex an argument to pursue here as my focus is on an intersectional definition of structural exploitation, rather than on exploitation as a family resemblance concept related to power.

29 Ehrenreich and Hochschild attribute this phenomenon to the fact that women in rich countries are now entering the workforce in larger numbers. This increase in numbers has not been accompanied by state support or an increase in men taking on an equal share of domestic labour. Ehrenreich and Hochschild (2003), p. 7-8.

30 International Labour Organization, 'Domestic Workers Across the World: Global and Regional Statistics and the Extent of Legal Protection', (Geneva: International Labour Office, 2013), p. 8. Domestic workers can also be employed by an agency, but the report argues that these workers are, in practice, likely to be included in this statistic due to a lack of an alternative category of classification (p. 10).

31 International Labour Organization (2013), p. 2.

32 Richard J. Arneson, 'What’s Wrong with Exploitation?', Ethics 91/2 (1981), 202-227, p. 203. 


\section{GLOBAL STRUCTURAL EXPLOITATION: TOWARDS AN INTERSECTIONAL DEFINITION}

engaged in productive labour create value over and above what is necessary for their subsistence, and this surplus value is appropriated by the capitalist class without remuneration. ${ }^{33}$ This is what constitutes the exploitation of one class (workers) by another class (capitalists). Thus, exploitation, for Marx, is necessarily structural.

However, as Arneson further points out, we generally think of exploitation as a normative concept, and even in Marx's works, it is unclear whether he used the term in an exclusively technical sense. ${ }^{34}$ Analytical Marxian debates about exploitation in the 1970s and 1980s revolved around whether or not exploitation constituted a moral wrong and if it did, what was wrong with it. Some theorists suggest there is nothing normatively problematic about exploitation; it is merely a technical term without evaluative content. ${ }^{35}$ However, many others reject that claim and maintain that exploitation is wrongful from a Marxian perspective.

One plausible argument to justify why 'Marx thinks exploitation an evil' is, as Nancy Holstrom argues, that 'Force, domination, unequal power and control are involved in exploitation both as preconditions and as consequences. ${ }^{36}$ Jeffrey Reiman calls this a 'force-inclusive' definition of exploitation and develops it further. He argues that the force involved in exploitation is structural rather than overt and it is invisible in capitalism because 'overt force is supplanted by force built into the very structure of the system of ownership.' He writes,

Because there is the human institution of private ownership of the means of production by a small class of people, the members of the class of nonowners are forced to work for those people - though not necessarily forced by those people - in order to get a crack at a living at all. Accordingly, I take it that the force in our definition must apply not only to overt violence, but to force that is 'structural,' both in its effects and in its origins. ${ }^{37}$

The origin of structural force is the class system; as capitalists own the means of production, nonowners are forced to work for them. The effect of structural force is that it positions different social groups such that they have a particular 'array of fates.' 38 The proletariat will have a small range of options for action - a small pool of jobs that they must choose from to earn a wage to survive.

33 Arneson (1981), p. 203. See also Karl Marx (Ben Fowkes , trans.), Capital Volume I, Vol. 1 (London: Penguin Books, 1990), p. 325.

34 Arneson (1981), p. 202.

35 Allen W. Wood, 'Exploitation', Social Philosophy and Policy 12/2 (1995), 136-158.

36 Nancy Holstrom, 'Exploitation', Canadian Journal of Philosophy 7/2 (1977), 353-369, p. 364.

37 Jeffrey Reiman, 'Exploitation, Force, and the Moral Assessment of Capitalism: Thoughts on Roemer and Cohen', Philosophy \& Public Affairs 16/1 (1987), 3-41, p. 12. 38 Ibid. 
Structural force operates to make individuals' decisions appear rational and uncoerced. For example, a man's decision to work in a local factory appears to be a rational choice given his circumstances. However, his decision can be said to be forced 'provided that the whole array of alternatives can be said to be forced upon him.'39 The man's decision is forced because he has few options for action: he needs to earn a wage to buy food, shelter and clothing, and he is restricted to working in his local area as he cannot afford to relocate. Thus, Marx argues that the wage worker is compelled to sell himself of his own free will. ${ }^{40}$ In capitalism, force is invisible, and it only becomes visible when 'if, instead of taking a single capitalist and a single labourer, we take the class of capitalists and the class of labourers as a whole. ${ }^{41}$ On this forceinclusive Marxian definition of exploitation, then, workers are forced to engage in productive labour for capitalists who systematically extract their surplus labour.

The force-inclusive Marxian definition of exploitation has significant explanatory power; it explains how exploitation can be conceived of as a forced transfer between groups embedded in the economic system. Structural exploitation relies on power relations between classes that constitute the foundation of the capitalist political economy. For the remainder of this paper, I consider the force-inclusive interpretation to be the 'Marxist definition.'

The Marxist definition has been criticised from several viewpoints because of its reliance on a narrow interpretation of 'productive labour.' Feminists argue that the Marxist conception of productive labour is an overtly masculinist interpretation of labour and ignores women's 'reproductive' labour in the home, upon which capitalism is entirely dependent. Critical race theorists have argued that it is 'race-blind' and fails to explain the ways in which groups racialised as inferior are subject to specific types of exploitation. Contemporary post-Fordist Marxian theorists have criticised its reliance on the production of material goods to the neglect of immaterial or 'affective' labour.

\section{a) Feminist Critiques}

Feminists have critiqued the Marxist definition for its over-reliance on 'productive' labour and its neglect of 'reproductive' labour. As Mariarosa Dalla Costa and Selma James argued in their influential 1972 pamphlet 'The Power of Women and the Subversion of Community,' since Marx, the exploitation of wage labourers has been understood to be the foundation of capitalist society; however, this analysis obscures the labour of the non-wage labourer, that is,

39 Ibid, p. 16.

40 Marx quoted in ibid.

41 Marx quoted in ibid, p. 18. 


\section{GLOBAL STRUCTURAL EXPLOITATION: TOWARDS AN INTERSECTIONAL DEFINITION}

housewives. Male workers' exploitation depends on the unpaid exploitation of the female proletarian and bourgeois housewife. Women's work is central to the reproduction of the labour force in two ways: by reproducing the labour of the male wage worker (doing the necessary housework, cooking his meals and providing sexual and emotional services) and producing future generations of wage workers. As such, 'domestic work produces not merely use values, but is essential to the production of surplus value.' ${ }^{2}$ The creation of surplus value would not be possible without this reproductive labour.

The occlusion of 'women's work' from Marxist (and liberal) economic analysis has been so successful because of its association with nature. As Dalla Costa and James put it, 'Where women are concerned, their labour appears to be a personal service outside of capital.'43 Silvia Federici claims that capital 'mystifies' housework 'as a natural resource.' 44 This has been reinforced by the emergence of the ideal of the nuclear family, with the ideological conception of a woman as wife and mother taking care of the home and the male 'breadwinner' providing for his family. Maria Mies argues that capitalism created 'the housewife as social category.' 45

In light of these critiques, some feminists have argued for a 'dual-systems' theory; that is, we must theorise capitalism and patriarchy and the ways in which they intersect. ${ }^{46}$ Capitalism refers to economic exploitation, but patriarchy, as a psychological and cultural phenomenon, explains men's dominance over women. However, some Marxist/socialist feminists have argued against such an approach, claiming that capitalism depends on patriarchy; they are one system. ${ }^{47}$ It is wrong to claim that patriarchy can be separated and analysed independently of capitalist economic relations. However, this raises the question of how Marxist/socialist feminists can salvage the concept of exploitation.

One approach is to expand what we mean by labour. Mies declares that she will continue to use the term 'productive labour' but with a feminist meaning: 'the broad sense of producing use values for the satisfaction of human needs.' 48

\footnotetext{
42 Mariarosa Dalla Costa and Selma James, The Power of Women and the Subversion of Community (New York: Pétroleuse Press, 2010), p. 16.

43 Costa and James (1972), p. 10.

44 Silvia Federici, Caliban and the Witch (New York: Autonomedia, 2004), p. 11.

45 Mies (2014), p. 105.

46 See Heidi Hartmann, 'The Unhappy Marriage of Marxism and Feminism: Towards a More Progressive Union', in Lydia Sargent (ed.), Women and Revolution: A Discussion of the Unhappy Marriage of Marxism and Feminism (Boston: South End Press, 1981), 1-43.

47 Iris Young, 'Beyond the Unhappy Marriage: Critique of the Dual Systems Theory', in Lydia Sargent (ed.), Women and Revolution: A Discussion of the Unhappy Marriage of Marxism and Feminism (Boston: South End Press, 1981), 43-71; Mies (2014), p. 38.

48 Mies (2014), p. 47.
} 
Other Marxist-feminists, however, have contested the idea that domestic labour can be conceived of as 'productive labour.' According to Lise Vogel, the term 'productive labour' should be reserved for labour that creates surplus value in the process of commodity production. In a working day, the labourer spends part of the day doing 'necessary labour' - earning a wage that allows the worker to purchase his means of subsistence - and the rest of the day is spent doing 'surplus labour,' which is appropriated by the capitalist. ${ }^{49}$ Domestic labour is different because it involves the creation of use values that are immediately consumed, rather than surplus values that are appropriated by capitalists. It does not constitute 'productive labour' in the technical Marxist sense because it does not produce surplus value. ${ }^{50}$

Another possibility is to argue that domestic labour constitutes 'unproductive labour,' but this too is problematic because Marx defined unproductive labour as 'labour which is not exchanged with capital, but directly with revenue, that is, with wages and profits. ${ }^{51}$ Domestic labour performed by housewives is not exchanged for money; it takes place 'outside the processes of production. ${ }^{52}$ This leads Terry Fee to argue that domestic labour constitutes neither 'productive' nor 'unproductive' labour in the technical senses described by Marx, but something else. What this 'something else' refers to is unclear within the Marxist framework. Nonetheless, it is clear that 'women's work, regardless of its productiveness or unproductiveness lies at the very heart of capitalism.' 53

In sum, the feminist critics of Marx exposed that the classic Marxist theory of exploitation carries significant conceptual baggage. If exploitation is defined as requiring the production of surplus value dependent on a narrow conception of productive labour, then we are missing the ways in which women are specifically exploited through the unwaged labour they do when taking care of and reproducing the labour force. Domestic or reproductive labour is outside the relations of production and, therefore, according to the Marxist definition, not 'exploited.' Moreover, whether the Marxist concept of productive labour can be amended to accommodate this critique is debatable.

\section{b) Critical Race/Post-colonial Critiques}

The Marxian/socialist-feminist critiques of the traditional Marxist concepts of labour and surplus value are compelling. They have been powerfully critiqued,

\footnotetext{
49 Lise Vogel, 'Domestic Labour Revisited', Science \& Society 64/2 (2000), 151-170, p. 160; Marx (1990), pp. 324-25. 50 Vogel (2000), p. 162.

51 Marx, 'Theories of Surplus Value Part I', quoted in Terry Fee, 'Domestic Labor: An Analysis of Housework and its Relation to the Production Process', Review of Radical Political Economics 8/1 (1976), 1-8, p. 5.

52 Marx quoted in Fee (1976), p. 6.

53 Fee (1976), p. 7.
} 


\section{GLOBAL STRUCTURAL EXPLOITATION: TOWARDS AN INTERSECTIONAL DEFINITION}

however, by Black feminists who claim that not all women are exploited as housewives. The history of sexual inequality between Black men and women, and that of Black women's labour force participation, are different from white women's history. ${ }^{54}$

Gloria Joseph argues that slavery 'played a curious role in bringing about equality among Black men and women.'55 Inequality emerged in a different way between Black men and women, from white men and women, because they started out as equally enslaved. Both Black men and women were forced to work, and Black women's participation in the labour force continued to resemble their tasks under slavery for generations. Angela Davis documents how, 25 years after emancipation, of the one million Black girls and women employed in the US, '38.7 percent [worked] in agriculture; 30.8 percent in household domestic service; 15.6 percent in laundry work; and a negligible 2.8 percent in manufacturing. The few who found jobs in industry usually performed the dirtiest and lowest-paid work. '56 This pattern of Black women's labour force participation continued until World War II. According to the 1940 census, $59.5 \%$ of Black women in the labour force were domestic workers and $16 \%$ still worked in the fields. ${ }^{57}$

Joseph argues, therefore, that 'the categories of Marxism are sex-blind and race-blind. ${ }^{58}$ Why is it that Black women were exploited formerly as slaves and subsequently in domestic service? More specifically, at a conceptual level, how can the categories of productive labour and surplus value explain why certain types of individuals fill particular places in the hierarchical division of labour? Heidi Hartmann puts the point as follows: 'Capitalist development creates the places for a hierarchy of workers, but traditional marxist categories cannot tell us who will fill which places. Gender and racial hierarchies determine who fills the empty places.'59 Without analysing gender, 'race' and class we cannot explain the ways in which different social groups are differentially exploited. ${ }^{60}$

Third World and post-colonial scholars have also exposed the deficiency of the dual-systems theory approach that interprets capitalist exploitation as

54 Gloria Joseph, 'The Incompatible Menage à Trois: Marxism, Feminism, and Racism' in Lydia Sargent (ed.), Women and Revolution: A Discussion of the Unhappy Marriage of Marxism and Feminism (Boston: South End Press, 1981), 91-109, p. 94.

55 Ibid.

56 Angela Davis, Women, Race and Class (New York: Vintage Books, 1983), p. 77.

57 Davis (1983), p. 86.

58 Joseph (1981), p. 93.

59 Hartmann (1981), p. 18.

60 We might think that Black feminist critiques of socialist and Marxist feminists who argue that capitalist exploitation of the male wage worker depends on the invisible exploitation of the female housewife are peculiar to the context of the United States, where slavery played a foundational historical role. Chattel slavery, however, was widespread in the 'New World' and foundational in the development of modern Europe. 
an economic phenomenon and male domination as an eternal psychological/ cultural phenomenon. As Joseph states, 'Third World people have a documented history that contradicts the "since the beginning of humankind male supremacy" doctrine. ${ }^{61}$ Like the Marxist/socialist-feminists, these thinkers invite us to find an integrated conception of exploitation; however, it has to be one that understands how capitalism preys upon 'race' as well as gender and class.

\section{c) Post-Fordist Critiques}

The final critique comes from Marxian theorists theorizing post-Fordist economies. Michael Hardt argues that the industrial revolution introduced a shift from agricultural jobs to mining and industry. In this context, the Marxist theory of exploitation made sense. However, we have moved to a new economic paradigm and are no longer living in an age of industrialisation; rather, we are living in one of 'informatisation': 'The passage toward an informational economy involves necessarily a change in the quality of labor and the nature of the labouring processes ... Information, communication, knowledge, and affect come to play a foundational role in the production process. ${ }^{62}$

The economies of rich countries now depend on the service industries. Marx, however, excluded services from the concept of 'productive labour.' He emphasised the relation between productive labour and commodities: 'Labour remains productive as long as it objectifies itself in commodities. ${ }^{\text {'63 }}$ Marx repeatedly makes the point that labour is only productive, and an exponent of labour-power is only a productive worker, if it or he creates surplus-value directly, i.e. the only productive labour is that which is directly consumed in the course of production for the valorization of capital. ${ }^{164}$ Service work, according to Marx, is a use value exchanged for money. ${ }^{65}$ Some service work, however, does valorise capital. Although Milton writing Paradise Lost cannot be considered a productive worker, the protelarian writer who churns out material for a publisher is because 'his production is taken over by capital and only occurs in order to increase it. ${ }^{96}$ The singer who sings to entertain is not a productive labourer, but one who is managed by an entrepreneur to make money is a productive labourer because 'she produces capital directly. ${ }^{67}$ It is not the content of labour that determines whether it is productive or not, but how it is deployed in relation to capital.

61 Joseph (1981), p. 98.

62 Michael Hardt, 'Affective Labor', boundary 2 26/2 (1999), 89-100, p. 93.

63 Marx (1990), p. 1039.

$64 \operatorname{Marx}(1990)$, p. 1038.

65 Marx (1990), p. 1041.

66 Marx (1990), p. 1044.

67 Ibid. 


\section{GLOBAL STRUCTURAL EXPLOITATION: TOWARDS AN INTERSECTIONAL DEFINITION}

Marx did not devote much time to considering services, however, because at the time of writing they were of 'microscopic significance compared with the mass of capitalist production.' ${ }^{68}$ This is not true today. Moreover, the rise of the service industries has unveiled new forms of labour, that already existed, but have now become more prevalent. Hardt argues that in this new era, production does not result in material or durable goods; instead, the labour involved is 'immaterial labor - that is, labor that produces an immaterial good, such as a service, knowledge, or communication. ${ }^{69}$ There are at least two faces of immaterial labour. The first is associated with the rise of computers, whereby 'the manipulation of symbols and information' becomes a key skill in the workforce. ${ }^{70}$ The second is 'affective labour,' which is the 'the creation and manipulation of affects ${ }^{\text {} 71}$ through communication and bodily contact, such as in the entertainment industry or health services, respectively. ${ }^{72}$

This new economic framework challenges the traditional Marxist conception of exploitation because the immaterial/affective labour that has gone into producing an outcome (knowledge, manipulation of emotions) is not measurable in the way that the surplus value generated from the creation of a material product is measurable. For instance, it is not possible to measure the level of effort someone puts in to display particular emotions for other people's benefit. ${ }^{73}$ Again, it challenges what is meant by 'productive labour.' On this view, the Marxist conception of productive labour is outdated in the contemporary predominantly service-based economy, where immaterial labour does not yield surplus value in the same way as the classic interpretation of productive labour. In fact, Hardt and Negri go so far as to consider the orthodox Marxist concept of productive labour obsolete. ${ }^{74}$

In sum, feminist, anti-racist/post-colonial and contemporary Marxian theorists have exposed the shortcomings of the traditional Marxist conception of exploitation. The concept of 'productive labour' is masculinist and outdated, occluding domestic and reproductive labour and contemporary forms of immaterial/affective labour. It is also deficient in explaining why certain social groups fill particular places in the labour hierarchy. While it may be technically

68 Ibid.

69 Hardt (1999), p. 94.

70 Ibid.

71 Ibid, p. 96.

72 Ibid, p. 95 .

73 Arlie Hochschild describes emotional labour as the suppression of one's own feelings to sustain a demeanour that produces the proper state of mind in others, and she demonstrates this with the example of airline attendants. Arlie Russell Hochschild, The Managed Heart: Commercialization of Human Feeling (University of California Press, 2003), p. 7

74 David Harvie, 'All Labour Produces Value for Capital and We All Struggle Against Value', The Commoner 10 (2005), 132-171, p. 163 . 
correct within the Marxist framework (which is not something I am disputing), it does not capture contemporary forms of global structural exploitation.

When we consider the global migration of women as domestic labourers and caregivers, for example, all the shortcomings of the technical Marxist definition of exploitation discussed in this section are exposed. First, their work is classified as 'unproductive labour' and is thus not technically exploited. Recall that for Marx, some service work can indeed be considered as productive labour: migrant domestic workers who work for an agency are producing surplus value that can be appropriated by the agency, thus valorising capital. However, migrant domestic workers employed directly by individuals and living in their household presumably do not produce surplus value in the technical Marxist sense; rather, they produce use values, which are directly consumed by the employers and which they exchange for money.

Second, this movement of migrant domestic labour is fundamentally gendered and racialised; the vast majority of these workers are women, and they are employed in different locales depending on local prejudices and racial hierarchies. ${ }^{75}$

Third, the work of these migrant women often involves emotional labour. ${ }^{76}$ Wealthy, white women hire nannies instead of sending their children to daycare because they want them to develop personal and emotional relationships with their carers. ${ }^{77}$ Although these workers are often considered 'part of the family,' they are let go when their caring responsibilities are no longer required; however, the advantage is that they can be expected to do 'favours' and work longer hours out of a sense of familial duty. ${ }^{78}$

Thus, in the global domestic labour/care economy, we find a serious test for the technical Marxist definition of exploitation. Perhaps this brings us back to the distinction between a technical and normative definition of exploitation. If we want a strict Marxist technical definition, we will simply accept that these workers are not 'exploited.' If, however, we are looking for a definition that has normative and critical purchase in the contemporary world, whereby we can argue that these women are exploited, we may have to move beyond the Marxist definition.

Neither the liberal conceptions of transactional exploitation nor the structural Marxist conception of exploitation can account for this form of global structural

75 Bridget Anderson, 'Just Another Job? The Commodification of Domestic Labor', in Barbara Ehrenreich and Arlie Russell Hochschild (eds.), Global Woman: Nannies, Maids and Sex Workers in the New Economy (London: Granta Books, 2003), 104-115, p. 108.

76 On emotional labour, see Hochschild (2003).

77 Anderson (2003), p. 111-112.

78 Ibid, p. 112. 
exploitation. This is problematic because we tend to think of these migrant domestic workers as some of the most exploited people in the contemporary global economy because, as the ILO points out, they often lack access to minimum labour protections, including minimum wage guarantees, restrictions on working hours and maternity or annual leave. ${ }^{79}$ Their work is often invisible and it is difficult for these workers to collectively organise because they are isolated in households and lack access to other similarly placed workers or organised labour. It is for these reasons that I now move away from the Marxist definition of exploitation and argue that we must pursue a fundamentally intersectional conception of exploitation if we want to find a definition of contemporary global structural exploitation with normative purchase.

\section{Towards an Intersectional Definition of Structural Exploitation}

Feminist, anti-racist and contemporary Marxian theorists have offered compelling critiques of the traditional Marxist theory of structural exploitation, although there are few positive definitions that can replace it. Here, I assess two - from Maria Mies and Iris Marion Young - and pick out their advantages and disadvantages. I propose a positive definition of structural exploitation arising from my critiques of these definitions.

The first intersectional definition in the literature comes from Maria Mies in Patriarchy and Accumulation on a World Scale. Mies takes issue with the Marxist argument that exploitation merely involves the appropriation of 'surplus,' rather than the taking of the necessary means of subsistence from other groups. Mies' thesis is that two processes have enabled the development of capitalism - colonisation and housewifisation. In the early modern period, the extraction of human labour (slavery) and natural resources from the colonies and the housewifisation of bourgeois and then working class women provided the foundations for the development of the capitalist political economy. Women, colonial subjects and colonial land were 'naturalised' and defined as outside of civilisation and part of nature, ${ }^{80}$ thus enabling their resources to be extracted and for this process to be considered as outside the processes of production. Capital accumulation historically has depended upon the naturalisation of certain subjects in order to invisibly exploit them. The processes of colonisation and housewifisation have created the bedrock upon which men have become 'free' to sell their labour and be exploited in the classical Marxist sense. ${ }^{81} \mathrm{It}$ is only with this broader definition of exploitation that this underlying form of structural exploitation, of groups and objects that are naturalised and

79 International Labour Organization (2013), p. 1.

80 Mies (2014), p. 75.

81 Mies (2014), p. 110. 
considered outside the relations of production, becomes visible. Mies argues that there are two concepts of structural exploitation:

In contrast to Marx, I consider the capitalist production process as one which comprises both: the superexploitation of the nonwage labourers (women, colonies, peasants) upon which wage labour exploitation is then possible. I define their exploitation as superexploitation because it is not based on the appropriation (by the capitalist) of the time and labour above the 'necessary' labour time, the surplus labour, but of the time and labour necessary for people's own survival or subsistence production. It is not compensated for by a wage, the size of which is calculated on the 'necessary' reproduction costs of the labourer, but is mainly determined by force or coercive institutions. $^{82}$

Mies retains the Marxist sense of exploitation and adds 'superexploitation,' which includes the exploitation of women's reproductive labour, slave labour, the colonies' natural resources and essentially anything forcibly stolen in the pursuit of capital accumulation that is necessary for subsistence. Superexploitation includes the appropriation of anything 'naturalised' (i.e. considered outside the processes of production) that in fact enables production.

I suggest contra-Mies, however, that we should search for one integrated conception of structural exploitation and exclude the exploitation of natural resources, which Mies wants to include in the concept of superexploitation. The 'expropriation' of natural resources can be included in the concept of 'accumulation,' which does not have to be considered as 'primitive' or 'original'; as contemporary theorists are arguing, it is an ongoing process that occurs globally and not only in the colonies. 'Accumulation by dispossession'83 or 'accumulation by extra-economic means' ${ }^{\text {'4 }}$ refers to the capturing of resources by capital. I suggest that when conceptualising a definition of structural exploitation, in contrast to Mies, we should focus on agents rather than objects. Structural exploitation is a concept that refers to power relations between groups of agents.

Iris Marion Young provides a more integrated conception of structural exploitation which considers it in terms of power relations between groups. In Young's discussion of exploitation in Justice and the Politics of Difference, she bases her understanding of structural exploitation on the force-inclusive

82 Mies (2014), p. 48.

83 David Harvey, The New Imperialism (Oxford: Oxford University Press, 2003).

84 Jim Glassman, 'Primitive Accumulation, Accumulation by Dispossession, Accumulation by "Extra-Economic" Means', Progress in Human Geography 30/5 (2006), 608-625. 
Marxist definition; however, she does this in a way that does not rely on the concept of productive labour defined as labour that produces surplus value. ${ }^{85}$

Young draws on C.B. Macpherson's argument that what is involved in capitalist economic relations is a transfer of power from non-owners to owners of the means of production. In a capitalist society, non-owners have no extractive power, and so they have to continuously sell their labour power to owners; the work of the labourer and the product of the work are owned by the capitalists. ${ }^{86}$ The measurable transfer from non-owners to owners is labour power; however, Macpherson argues that the non-owners' powers 'are diminished by more than the amount of the transfer. ${ }^{87}$ Labouring not only uses a man's labour power but also reduces his developmental power - 'his ability to use his energies and capacities for all other purposes, that is, his ability to engage in activities which are simply a direct source of enjoyment and not a means of material production. ${ }^{88}$ Young is inspired by this thought because for her, oppression is defined as 'the institutional constraint on self-development. ${ }^{89}$ Justice requires that individuals have the opportunity for self-development. If groups are institutionally or structurally prevented from realising self-development, they are oppressed. ${ }^{90}$

According to Young, the injustice of structural exploitation is that 'the energies of the have-nots are continuously expended to maintain and augment the power, status, and wealth of the haves. ${ }^{91} \mathrm{~A}$ continual forced transfer of energies from disadvantaged social groups to advantaged social groups is built into the capitalist political economy, inhibiting the self-development of the exploited social groups and enhancing the status, wealth or power of the exploiter groups. The inhibition of self-development is what renders exploitation a form of oppression and, hence, an injustice.

Releasing the concept of structural exploitation from the orthodox Marxist conception of productive labour in this way, by conceiving of it as a forced transfer of energies from disadvantaged groups to advantaged groups, allows more scope to discuss exploitative relations between non-economic groups. Indeed, Young uses this idea to explain exploitation along the lines of gender and 'race.'

85 Young (1990), p. 48-53.

86 C. B Macpherson, 'The Problems of a Non-Market Theory of Democracy' in C. B. Macpherson (ed.), Democratic Theory: Essays in Retrieval (Oxford: Clarendon Press, 1973), 39-70, p. 65.

87 Macpherson (1973), p. 64.

88 Ibid, p. 66.

89 Young (1990), p. 37.

90 Oppression manifests itself in at least five forms: exploitation, marginalisation, powerlessness, cultural imperialism and violence. See Young (1990), Ch. 2.

91 Ibid, p. 50 . 
Young draws on Ann Ferguson's concept of 'sex/affective production' (a precursor to the Hardtian conception of affective labour). Ferguson argues that human need includes emotional and sexual nurturance, as well as the material means of subsistence. ${ }^{92}$ She argues that given the number of hours women expend not only in wage labour but also in sex/affective production, they do more work and receive fewer benefits, 'thus allowing men to appropriate a social surplus of goods, sex/affective labour and services from women.'93 Young interprets this to mean that 'women undergo specific forms of gender exploitation in which their energies and power are expended, often unnoticed and unacknowledged, usually to benefit men by releasing them for more important and creative work, enhancing their status or the environment around them, or providing them with sexual or emotional service.'94

Young brings in 'race' by drawing on Al Szymanski's theory that class is necessarily connected to 'race'; the capitalist mode of production reproduces 'races' to legitimate the degrading functions of certain social groups. ${ }^{95} \mathrm{He}$ argues that, 'Capitalism continually generates racism against the specially exploited menial laborers who are drawn into the lowest rungs of the economy.' 96 Young suggests that, "Wherever there is racism, there is the assumption, more or less enforced, that members of the oppressed racial groups are or ought to be servants of those, or some of those, in the privileged group.' 97 In the contemporary US, jobs such as chambermaids and porters - jobs which 'entail a transfer of energies whereby the servers enhance the status of the served' - are often filled by African-American and Latino workers. ${ }^{98}$

On the Youngian approach, then, structural exploitation draws on the Marxist force-inclusive conception because it consists in a forced transfer from social groups that are structurally positioned so as to have few options, constrained not only due to not owning the means of production but also due to gender and 'race' hierarchies. Instead of simply transferring their surplus labour, however, they are transferring 'energies,' because in labouring for a wage more than surplus labour is given up, meaning that these groups are constrained in their opportunities for self-development. This forced transfer of energies from socially disadvantaged groups enables exploiter groups to have more opportunities for self-development and enhances their power, status and wealth. Young's work is an important step towards defining structural exploitation in a way that builds

92 Ann Ferguson, Blood at the Root: Motherhood, Sexuality and Male Dominance (London: Pandora Press, 1989), p. 95. 93 Ibid.

94 Young (1990), p. 51.

95 Al Szymanski, 'The Structure of Race', Review of Radical Political Economics 17/4 (1985), 106-120, p. 109.

96 Ibid, p. 112.

97 Young (1990), p. 52.

98 Ibid. 


\section{GLOBAL STRUCTURAL EXPLOITATION: TOWARDS AN INTERSECTIONAL DEFINITION}

on Marxian insights that structural exploitation is a relationship between groups built into the economic system, but broadening the scope of the definition to include the critiques outlined here. The key insight of Young's definition is that it fundamentally includes an account of the way in which structural exploitation preys upon pre-existing gendered and racialised hierarchies, and reinforces or constitutes those hierarchies. It explains why certain groups fill particular places in the labour hierarchy and includes reproductive, unproductive and immaterial/affective labour.

However, the problem is that it is unclear what Young means by 'energies.' What exactly are 'energies' and how can we measure them? One of the reasons why the technical Marxist definition of exploitation has remained useful over time is that it identifies something that can be quantified - surplus value and that can be used to objectively calculate the rate of exploitation. Without a definition of energies and an explanation regarding why certain individuals have different amounts of energies and a way to measure this, the Youngian definition is less useful.

Young retains the insight from the Marxist definition that exploitation is a forced transfer between groups. Young's work is particularly helpful because it refers to transfers from disadvantaged social groups to advantaged social groups, expanding the notion of who can be exploited. However, I suggest, as an amendment to Young's definition, that we use the concept of 'productive powers' rather than energies to describe what is forcibly transferred. The term 'productive power' is borrowed from C.B. MacPherson and refers to both labour power, which according to Marx is anything that produces use values, and developmental power, which refers to one's ability to develop as an autonomous agent. This can include, then, reproductive labour in the home (both in terms of domestic labour and child rearing) and unproductive labour (the work of migrant domestic workers); furthermore, it includes slave labour and the various forms of labour that are coming to dominate contemporary economies (immaterial and affective labour - the production of information, knowledge or symbols and the manipulation of affects). Thus, I propose the following definition:

Structural exploitation refers to the forced transfer of productive powers from groups positioned as socially inferior to the advantage of groups positioned as socially superior.

This definition has several advantages. First, by focusing on 'productive power' rather than 'productive labour,' it includes what has been excluded by the technical Marxist definition: reproductive, unproductive, affective/ immaterial and slave labour. Second, the definition is neutral regarding which 
groups are socially inferior/superior in different socio-historical contexts (for instance, caste in India, 'race' in the US, colonial subjects globally). Third, this definition can explain why exploitation occurs along axes other than class, by including as part of the definition the idea that structural exploitation preys upon pre-existing social stratifications. Finally, the definition conceptualises structural exploitation as a power relationship between groups embedded in the socio-economic system. The 'forced transfer' of productive power from socially disadvantaged groups to advantaged groups structures possibilities for action on the part of those groups, and continually reconstitutes those social stratifications in the process.

An intersectional definition of global structural exploitation is necessary because economic exploitation is enabled by theories of the "natural' inferiority of particular social groups, and these stereotypes and biases provide a justification for the exploitation of these groups. This can be overt, as in the case of chattel slavery, where an outright propaganda war was waged against African people. It can also be more subtle, as in the contemporary context, with Third World women being portrayed as naturally suitable employees in sweatshops because of their 'nimble fingers,' docility and suitability for tedious, repetitious work, or their suitability as domestic labourers and caregivers. ${ }^{99}$ The definition of structural exploitation proposed here captures the way in which capital preys upon not only the economic subordination of these groups but also their social positioning in globalised gendered and racialised hierarchies.

One disadvantage of the definition proposed here is that it does not provide an objectively quantifiable standard in the way the classical Marxist definition does. Surplus labour is quantifiable, and thus the rate of exploitation is also quantifiable (at least in theory if not in practice). ${ }^{100}$ This is certainly a disadvantage, and it is the basis on which I critiqued Young's definition. However, what distinguishes this definition from Young's is that by tying exploitation to productive power, rather than the vaguer concept of 'energies,' it becomes more precise. Productive power, referring to labour and developmental power, is more specific than the general idea of 'energy.' However, the concept of productive power is still a lot less precise than the concept of productive labour which produces surplus value.

We have to ask, however, given the forceful critiques of Marx's conception of productive labour, whether a theory of structural exploitation should depend on it more generally. The view outlined here does not necessarily override the

99 Diane Elson and Ruth Pearson, “Nimble Fingers Make Cheap Workers”: An Analysis of Women's Employment in Third World Export Manufacturing', Feminist Review 7/1 (1981), 87-107, p. 93.

100 Diane Elson, Value: The Representation of Labour in Capitalism (London: Verso, 2015), p. 120. 


\section{GLOBAL STRUCTURAL EXPLOITATION: TOWARDS AN INTERSECTIONAL DEFINITION}

technical Marxist definition of exploitation as a tool for economic analysis; instead, it provides a normative conception of structural exploitation fit for the contemporary context. As political theorists, rather than economists, we are interested in more than a mathematical tool. What we need from a conception of exploitation is to be able to capture what is wrong with it, rather than merely to define it. In this essay, I have been concerned with a descriptive rather than a normative account of exploitation. However, I conjecture that a definition of exploitation will necessarily be normative. This is what the debates over the Marxist conception boiled down to - whether it was necessarily normative or not. Within the Marxist framework, when we adopt a force-inclusive definition of exploitation, as Holstrom pointed out, the fact that force is involved suggests exploitation is inherently wrongful. Moreover, when we build an intersectional definition of exploitation that tries to incorporate the ways in which particular social groups are structurally exploited, the definition will be normatively laden. Furthermore, the point of defining global structural exploitation here is to identify it as a form of global injustice.

Just briefly, then, let me outline the normative implications of this definition of structural exploitation. Structural exploitation is wrong, on this account, because a) it is a forced transfer of the labour and developmental power of certain social groups to others; b) it asserts the power of advantaged social groups over disadvantaged social groups; and c) it both entrenches and increases the benefits of advantaged social groups, thus reinforcing class, 'race,' caste and gender hierarchies and re-constitutes those hierarchies for future generations. Thus, the implications are that it is a form of structural injustice.

Youngidentifies two forms ofinjustice: oppression and domination.Oppression is the systematic inhibition of self-development. This is implied directly in the concept of structural exploitation, which systematically drains the productive powers of exploited groups. Domination is the systematic inhibition of selfdetermination. Although this is not directly implied in the concept of structural exploitation in the same way as oppression, structural exploitation could reduce the possibility of self-determination because it reduces people's capacity to selfdetermine by draining their productive power. Structural exploitation is also difficult to self-determine or revolt against because of its nature (it is embedded in the capitalist economy). Each of these claims requires further elaboration and justification; however, at first glance, they seem obviously to follow from the intersectional definition of global structural exploitation proposed here. This view, then, is distinct from the liberal views discussed at the beginning. On the transactional accounts of exploitation, the wrongfulness of exploitation is explained by the unfair distribution within exchanges or unfairly taking 
advantage of another agent in a degrading way. On my view the normative concern lies not in the unfairness but in the force, the unequal power relations and the oppression implied by structural exploitation.

\section{Conclusion}

In this paper, I aimed to invite conceptual discussion regarding how global structural exploitation could be defined. Through an exposition and critique of liberal and Marxist conceptions of exploitation, I have offered an intersectional and structural definition. I argue that structural exploitation preys upon cleavages of disadvantage along the axes of class, 'race,' gender, caste and colonial subjugation. Structural exploitation both takes those subjects pre-positioned as socially inferior and constitutes subjects as socially inferior, and extracts their productive powers, reinforcing their disadvantage while maintaining gendered, racialised and classed power relations.

Unlike proponents of Marxian approaches, I do not consider structural exploitation as the exclusive definition of exploitation. Instead, I have suggested the possibility that exploitation is a family resemblance concept. The liberal debates about transactional exploitation revolve around what constitutes unfairly taking advantage of another agent in a transaction or taking advantage in a degrading way. Structural exploitation refers to the systematic forced transfer of the productive powers of groups positioned as socially inferior to groups positioned as socially superior. I have suggested that this is a form of oppression because it systematically inhibits the self-development of exploited groups. The next step is to develop a more thorough account of global structural exploitation as an injustice and to show how it operates in practice. ${ }^{101}$

Maeve McKeown

St Hilda's College,

University of Oxford

Email:maeve.mckeown@st-hildas.ox.ac.uk

\section{- the global justicenetwork}

101 I would like to thank the participants in the Justitia Amplificata/Wissenshaftkolleg zu Berlin "Structural Injustice" Workshop (February 2015) and members of the University of Brighton Philosophy Society for comments on an early draft of this paper. I would also like to thank Mirjam Müller, Ross Speer, Tamara Jugov and two anonymous referees for their very helpful written comments. 